\title{
The Influence of Learning Methods and Student Personality Types in Islamic Religion Lessons
}

\author{
Adri Lundeto \\ Institut Agama Islam Negeri (IAIN) Manado, Indonesia \\ Email: adri.lundeto@iain-manado.ac.id
}

\begin{abstract}
The learning educates pupils that the key predictors of academic success are educational concepts and learning theories. Learning is a double process of communication: the teacher as an educator teaches while students teach. This is a qualitative type of research. Qualitative research is an investigation process which produces descriptive data of people and observed conduct in written or spoken terms. An interdisciplinary strategy is applied in this study, integrating management, pedagogy, sociology and psychology techniques. Two types of data sources are used in this study: Primary data. Primary information. Primary data are collected in field research from informants who, in this case, are professors of Islamic Religious Education directly. Research and analytical results show that: 1) there have been difference between students who follow the co-operative method of learning and students who follow the conventional method of learning; 2) there has been no difference between students with introverted personality type and students with extraverted personality.
\end{abstract}

Keywords: Influence, Teaching Method, Personality, Islamic Religious Education.

\section{A. INTRODUCTION}

Islamic Religious Education as a process of ikhtiyariyah contains unique characteristics and characters, namely planting, developing, and strengthening faith values that become the mental-spiritual foundation of human beings in which attitudes and behaviour are manifested according to the rules of their religion (Abdi, 2018). The importance of one's faith is the whole person who expresses himself in the form of outward and spiritual behaviour, and he is the fundamental driving force/enforcer for one's behaviour (Alrabai, 2018).

The term strategy was initially being used in the military world, which was defined as using all military power to win a war (Bahiroh \& Suud, 2020). A person who plays a role in setting the strategy to win the battle before taking action will consider how the strength of the troops he has both in terms of quantity and quality; for example, the ability of each individual, the number and power of weapons, the motivation of his troops and so on (Biantoro, 2019). According to J.R. David, Education is defined in the strategic world as "a plan, method or set of activities to attain a specific educational objective." The learning strategy can therefore be interpreted as a plan which includes a number of activities to fulfill specified education objectives (Chowdhury, 2018). Learning can be divided into two, namely in general and in particular. Understanding learning, in general, is an activity carried out by educators in such a way so that the behaviour of students changes for the better (Huda et al., 2017). While learning is explicitly an activity that is carried out unconsciously and unintentionally. Therefore, learning must have a learning 
goal, which is a relatively constant change in behaviour that occurs because of an experience or practice (Jain et al., 2015).

Meanwhile learning is a process in which the surroundings of a person is actively managed to enable him or her to participate in certain behaviors under certain conditions or respond to particular schooling situations (Kistoro, 2021). Learning is the actualization of the curriculum that requires teachers to create and grow student activities following the plans that have been programmed (Lukens, 2000).

Islamic education also trains students' sensibility so that attitudes and behaviour are dominated by deep feelings of Islamic ethical and spiritual values (Manshur, 2020). They are trained to seek knowledge to satisfy intellectual curiosity or just for the benefit of the material world and to develop themselves as rational and pious beings who will later provide physical, moral and spiritual well-being for families, communities, and humanity. This view stems from a deep faith in Allah SWT (Mohamed et al., 2016).

On the basis of the Law Number 20 of 2003 on National Education Systems: national education strives to develop students' capacity for full Indonesian humanity (Moser, 2008). Namely, those people who trust in God the All-Powerful, who have knowledge and talent, who have a noble bodily and spiritual quality, who have a strong, intellectual, authentic, and responsible personality (Nugroho, 2019). It is strongly expected that every school will impact the establishment of a holy spirit in youngsters, so that pupils can develop religious behaviour (Paloutzian, Richardson \& Rambo, 1999). The extent of the influence depends, however, on other circumstances which may inspire children to understand religious ideas. Since religious education is essentially worthwhile (Safitri, 2018). Religious education is therefore more focused on the formation of spiritual guiding habits.

The influence of the formation of a religious spirit and religious behaviour in educational institutions, incredibly informal educational institutions (schools), depends a lot on the characteristics of the religious education provided at the school (Saniati \& Othman, 2019). This is because schools, in an Islamic perspective, function as media for the realization of education based on the goals of thought, aqidah and sharia to worship Allah and obey Him so that humans are protected from deviations from their nature (Suyanto et al., 2019). In this connection, to form a pious Muslim person, education through the school system should be given particular emphasis (Victorynie et al., 2020). This is because school education has a regular, graded program and follows clear and strict requirements (Tanjung, 2018). This supports the preparation of a more accommodating Islamic education program.

Teachers in using learning strategies should adjust to the conditions and atmosphere of the classroom, and of course, teachers are required to play more roles using varied learning strategies (Warsah, 2020). Each learning strategy has advantages and disadvantages. To avoid boring learning activities for students, a teacher needs to create good learning strategies that align with the needs of these students. 
Learning is a process of adding new information and abilities. When we think about what knowledge and skills students should have, then at that time, we should think about what strategies should be done so that all of this can be achieved effectively and efficiently (Zaiton \& Hishamuddin, 2012). This is very important to understand because what must be completed in determining learning strategies? Teachers always use more than one learning strategy. One approach is used to achieve one goal, while another system is also used to achieve other goals.

\section{B. METHOD}

This is a qualitative type of research. Qualitative research is an investigation process which produces descriptive data of people and observed conduct in written or spoken terms. An interdisciplinary strategy is applied in this study, integrating management, pedagogy, sociology and psychology techniques. Two types of data sources are used in this study: Primary data; primary data in field research are preliminary data directly gathered from informants who are, in this instance, instructors of Islamic Religious Education. Data from interviews and secondary data, data gathering in the form of existing documents and the impact of relevant research found by researchers are present in this study. The researchers utilize the technique of data collecting to monitor or observe ways in which people or groups can analyze and systematically record their behavior directly or observe them.

It is a simple random approach of sampling. The variables in this study comprised of two separate variables, namely the method of learning $\left(X_{1}\right)$, the personality type $\left(\mathrm{X}_{2}\right)$, and a dependent variable, namely Islamic religious education learning results $(\mathrm{Y})$. Cooperative (experimental) and conventional ways of learning (in the control class).

The personality type variable $\left(\mathrm{X}_{2}\right)$ is to map characteristics, characters and other behavioral factors to favorable results for individuals in this study. The individual's personality type is split into two components, namely extrovert and introvert. Therefore, the independent variable, namely the personality type $\left(X_{2}\right)$, consists of two categories: extrovert and introvert, represented by the score from the personality survey.

This study defines the student learning outcome variable (Y) operationally as the value achieved by measuring them after engaging in the Islamic Religious Education learning process. The result shows the level of skills obtained by students. A two-way variance analysis (ANOVA) is the method of data analysis that will be employed in this investigation as this study incorporates two elements at a time. Also, this study is called factor analysis because the analysis involves a crosscombination between the parts. The researcher utilizes the W-Stats tool to calculate this hypothesis test.

\section{RESULT AND DISCUSSION}

From hypothesis testing using two-way ANOVA (Analysis of Variance), the following results were obtained: 
Table 1 Results of Variant Analysis of Islamic Religious Education Learning Outcomes

\begin{tabular}{|l|c|c|c|c|c|c|}
\hline \multicolumn{1}{|c|}{ Variant Source } & $\begin{array}{c}\text { Number of } \\
\text { Squares }\end{array}$ & DK & $\begin{array}{c}\text { Square } \\
\text { Mean }\end{array}$ & F & $\begin{array}{c}\text { F-Sign } \\
\mathbf{( 5 \% )}\end{array}$ & Conclusion \\
\hline Learning Methods (A) & 4078.158 & 4 & 1358.719 & 17.086 & 2.667 & Significant \\
\hline Personality (B) & 3263.685 & 1 & 3263.685 & 41.024 & 3.906 & Significant \\
\hline
\end{tabular}

Source: Data processed

The F-count value of the variable for the study technique is 41.024 based upon the table above. Then it is known that F-count > F-table when examined with F-table $=3,906$. Those who follow the co-operative learning approach and those who follow the traditional learning method have an important difference in the outcomes of Islamic religious education. So the first hypothesis, which states "there is a difference in learning outcomes of Islamic Religious Education between students who follow the cooperative learning method and those who follow the conventional learning method", can be accepted.

The learning method is a plan that serves to assist students in their learning efforts to achieve each of their learning objectives. In this case, the teacher can use teaching materials or a production unit as a learning medium. The hypothesis test results indicate that students who follow conventional learning methods have higher learning outcomes than students who follow cooperative learning methods. This is not as previously thought that applying collaborative learning methods is expected to improve student learning outcomes.

However, the results of this study show the opposite. Namely, the learning outcomes of Islamic Religious Education can be optimal by using conventional learning methods. Traditional learning methods are considered more appropriate or suitable for improving student learning outcomes of Islamic Religious Education at MAN X than cooperative learning methods. This is due to many factors, including students not using collaborative approaches, and the culture of working together has not been embedded in them. They are used to and feel comfortable using conventional methods that have been applied in learning so far. In addition, the number of classes is so large, between 40-42 students per class, the application of cooperative learning methods becomes less effective and not conducive. So, from these difficulties, teachers are constrained in optimizing students' learning outcomes of Islamic Religious Education with cooperative learning methods.

Then to test the second hypothesis, based on the table above, the F-count value is 0.394 , then consulted with the F-table $=3.906$, it can be seen that the F-count $<$ F-table. Thus, it can be concluded that there is no significant difference in Islamic Religious Education learning outcomes between students with introverted personality types and students with extroverted personality types. So the second hypothesis, which states, "There is a difference in learning outcomes between students with introverted personality type and students with extrovert personality type", cannot be accepted. 
Extrovert and introvert personality types are two different groups of attitudes (outward and inward orientation), which are owned by individuals so that they become the characteristics of the individual in adapting to the environment that appears in activities, social preferences, courage to take risks, obedience to impulses, expression of feelings, depth of thought, and responsibility. The results showed that extroverted and introverted individuals did not significantly differ in students' academic achievement.

Therefore, the difference between extrovert and introvert personalities emphasizes their attitude towards their environment, not on differences in cognitive abilities. Extroverted students do not mean smarter than introverted students in receiving, thinking, and solving problems in building their knowledge of all the information or stimuli they encounter. There is a possibility that extroverted students have different learning outcomes from groups of introverted students. Still, the difference occurs because they tend to focus their attention on studying and processing teaching materials by utilizing stimulation following their characteristics.

Furthermore, to test the third hypothesis, based on the data above, the Fcount value for the interaction variables of learning methods and personality types is 10.019. Then if the value is consulted with the F-table $=3.906$, then the F-count $>$ Ftable. In this way, the results of Islamic Religious Education are influenced by interaction between learning methods and personality types. The treatment of cooperative methods of learning and personality types affects the learning results of Islamic Religious Education (independently). These results show that the third hypothesis, "there is an interacting influence on the outcomes of learning for Islamic Religious Education between modalities of learning and personality types," can be accepted.

The findings of this test are further enhanced by the results of other research concluding that the results of a person's language acquisition are caused by interactive elements, both internal and external, affecting the person. Interior characteristics, including age, anxiety, empathy, extroversion, introversion, risktaking, attitudes, and motivation. While external factors, such as learning methods, social environment and learning environment.

The results of hypothesis testing indicate that groups of students with introverted personalities with inward-oriented characteristics, such as: liking to be alone or not liking to socialize, are considered more suitable and effective if they follow conventional learning methods whose features do not require active and dominant communication. On the other hand, groups of students with extroverted personalities with outward-oriented characteristics, such as: socializing or socializing with other people, are considered more suitable and effective when participating in learning with cooperative learning methods whose features require interaction and communication skills quite dominant. Thus, it can be interpreted that the influence of each learning method, both conventional and cooperative, is closely related to each student's personality type. By knowing the student's personality type, the teacher can determine the suitable learning method for 
students. This is done to improve the quality of learning and learning outcomes.

\section{The Significance of Conventional Learning Methods}

Conventional (traditional) teaching methods are teaching methods commonly used by teachers. In Arabic, this method is called al arīgah al qadimah or al ariquah al taqlidiyyah, namely learning that positions the teacher as the primary source of knowledge (teacher-centred). The teacher transfers knowledge while students listen to what is said by the teacher, record things that are considered essential and then memorize them.

The stages of the traditional method are as follows: 1) Thorough preparation; 2) Speak using Arabic in class; 3) Do not move the material before it is steady; 4) Do not function the book not as a teacher, but as a supporting tool; 5) The teacher gives many tamriñät; 6) The teacher trains students to ask questions in Arabic; 7) The teacher gives encouragement or encouragement, and 8) The teacher creates a pleasant atmosphere.

In learning Islam, five classical methods are still used in various formal educational institutions (madrasas and public schools). The five methods are as follows: 1) tarjamah grammatical method (tarīqah al qaw $\bar{a} "$ id wa al tarjamah), 2) direct method (al arīqah al mubāsyirah), 3) reading method (țaīqah al qirā" ah), 4) audiolingual method (al arīqah al sam "iyyah al syafahiyyah); and 5) eclectic method (al arīqah al Intiqā" yeah).

\section{The Significance of Cooperative Learning Method}

Cooperative education has five fundamental parts, including: (1) positive dependency, (2) face-to-face engagement, (3) accountability, (4) social abilities, and (5) group briefing. Cooperative training techniques, including partner search, numbered heads (numbered managers together), STAD students' teams, and Learning Together (LT) among others techniques for cooperative learning.

The difference between conventional (traditional) learning and cooperative learning can be seen in the following table:

Table 2 Differences in Traditional Learning and Collaborative Learning

\begin{tabular}{|c|c|}
\hline From Traditional & To Cooperative Learning \\
\hline "A good class is a quiet class" & "Learning involves healthy noise" \\
\hline "Keep your eyes on your paper" & "Help your partner solve it" \\
\hline "Sit quietly" & "Get up and look what others did" \\
\hline "Talking is; cheating" & "Verbalize to learn" \\
\hline
\end{tabular}

Source: Data Processed

\section{The Influence of Personality Type on Student Learning Outcomes}

Inheritance and environment influence personality. Heredity refers at the time of conception to factors determined. The aspects of physical appearance, facial beauty, sex, temperament, muscle composition and reflexes, energy levels and 
biological cycles are often regarded by both parents. The hereditary approach suggests that an individual's ultimate explanation is the molecular structure of the genes on the chromosomes.

The environment also plays an important role in building a personality, in addition to inheritance. Culture, for instance, strengthens standards, attitudes and values handed from one generation to the next and provides continuity across time. An ideology vigorously promoted in one culture can influence another only moderately. For example, the Eastern people of Indonesia have gone through books, scholarships, the schools, the family and friends on subjects relating to crafting, success, competitiveness, liberty and work ethics. As a result, East Indonesians tend to be ambitious and aggressive compared to people who have grown up in cultures that have valued good cooperation with others.

History and environmental variables therefore constitute the fundamental determinants of personality. Heredity defines limitations or external limits, but an individual's complete potential is determined by adapting to environmental demands and expectations, including learning at school.

\section{CONCLUSION}

Research and analysis results show that there are differences between students who follow the cooperative learning technique and those who follow the conventional learning method in terms of learning outcomes of Islamic religious education. Where students who study by traditional methods tend to learn more than students who learn by cooperative methods. There is no difference in the results between students who are introverted and students with extroverted personalities; and interactive effects exist between study methods and personality.

\section{REFERENCES}

1. Abdi, M. I. (2018). The Implementation of Character Education in Kalimantan, Indonesia: Multi Site Studies. Dinamika Ilmu, 18(2), 305-321.

2. Alrabai, F. (2016). Factors underlying low achievement of Saudi EFL learners. International Journal of English Linguistics, 6(3), 21-37.

3. Alrabai, F. (2018). Learning English in Saudi Arabia. English as a foreign language in Saudi Arabia: New insights into teaching and learning English, 102-119.

4. Bahiroh, S., \& Suud, F. M. (2020). Preventive Counseling: A Religious Development Program at Boarding School in Yogyakarta. Humanities $\mathcal{E}$ Social Sciences Reviews, 8(2), 614-23.

5. Biantoro, O. F. (2019). Urgency of Islamic Religious Education Teachers in Character Building for Students in Junior High Schools. Al-Hayat: Journal of Islamic Education, 3(2), 178-199.

6. Chowdhury, M. (2018). Emphasizing morals, values, ethics, and character education in science education and science teaching. MOJES: Malaysian Online Journal of Educational Sciences, 4(2), 1-16. 
7. Huda, M., Jasmi, K. A., Mustari, I., Basiron, B., \& Sabani, N. (2017). Traditional wisdom on sustainable learning: An insightful view from Al-Zarnuji's Ta 'lim alMuta 'allim. SAGE Open, 7(1), 2158244017697160.

8. Jain, A., Bansal, R., Kumar, A., \& Singh, K. D. (2015). A comparative study of visual and auditory reaction times on the basis of gender and physical activity levels of medical first year students. International Journal of Applied and Basic Medical Research, 5(2), 124.

9. Lukens-Bull, R. A. (2000). Teaching morality: Javanese Islamic education in a globalizing era. Journal of Arabic and Islamic Studies, 3, 26-47.

10. Manshur, F. (2020). Typical Literary Works of Pesantren on Righteousness Teaching within Cultural Transformation. Journal of Social Studies Education Research, 11(4), 114-148.

11. Mohamed, S., Jasmi, K. A., \& Zailaini, M. A. (2016). Elements of Delivering Islamic Education through Islamic Morality in Several Malaysian Schools. Pertanika Journal of Social Sciences \& Humanities, 24(4).

12. Moser, S. (2008). Personality: a New Positionality?. Area, 40(3), 383-392.

13. Nugroho, P. (2019). Internalization of Tolerance Values in Islamic Education. Nadwa, 12(2), 197-228.

14. Paloutzian, R. F., Richardson, J. T., \& Rambo, L. R. (1999). Religious conversion and personality change. Journal of personality, 67(6), 1047-1079.

15. Safitri, D. D. (2018). Managing school based on character building in the context of religious school culture (Case in Indonesia). Journal of Social Studies Education Research, 9(4), 274-294.

16. Saniati, D., \& Othman, A. (2019). The Appreciation of An Islamic Education Curriculum: Lessons Learned from the Islamic Private Schools of West Kalimantan, Indonesia. O-JIE: Online Journal of Islamic Education, 7(1), 54-67.

17. Suyatno, J., Pambudi, D. I., \& Mardati, A. W. (2019). Strategy of Values Education in the Indonesian Education System. International Journal of Instruction, 12(1), 607-624.

18. Tanjung, E. F. (2018, July). Improving the Quality of Religious Islamic Education Learning through Collaborative Learning Approach in SMP Al-Muslimin Pandan District Tapanuli Tengah. In 2018 3rd International Conference on Education, Sports, Arts and Management Engineering (ICESAME 2018) (pp. 205207). Atlantis Press.

19. Victorynie, I., Husnaini, M., \& Amili, N. (2020). Model of religious character education: A case study in Al-Hilal Islamic Primary School Bekasi, Indonesia. Journal of Social Studies (JSS), 16(2), 103-120.

20. Warsah, I. (2020). Religious Educators: A Psychological Study of Qur'anic Verses Regarding Al-Rahmah. Al Quds, 4(2), 275-98.

21. Zaiton, M., \& Hishamuddin, S. (2012). Factors affecting student's interest in learning Islamic education. Journal of Education and practice, 3(13), 2222-1735. 